\section{Serum precipitins against respiratory tract pathogens in 522 'normal' children, and 48 cases of cystic fibrosis treated with cloxacillin}

Since 1964 one of us (D.L.) has treated all cases of cystic fibrosis (CF) with cloxacillin continuously from diagnosis or transfer, and since 1968 has monitored all cases with 6-monthly measurements of serum precipitins against potential respiratory tract pathogens. If the significance of serum precipitin findings in treated or untreated CF is to be assessed, then it is necessary to know the incidence of such precipitins in a 'normal' population at various ages. Accordingly, the present study of serum precipitin findings in 522 'normal' children was undertaken at Queen Mary's Hospital. A cross-sectional study of 48 children with CF is presented for comparison.

\section{Methods}

As it was judged neither socially nor ethically feasible to take blood samples from healthy children for this purpose, the following arrangements were made. The laboratory passed over to one of us (J.P.) all blood specimens which were surplus to requirements. These were then stored, and the case notes checked to ensure that the child did not fall into any of the following categories. (1) Currently under treatment or investigation for bacterial disease. (2) Suffering from any disease known to be likely to increase susceptibility to bacterial infection. (3) Recent history of substantial bacterial disease. (4) Long-term history of substantial or recurrent bacterial disease.

Towards the end of the series specimens were selected from under-represented age groups. 'Normal' refers to children who were selected in the sense that they were outpatients or inpatients of a children's hospital, but the exclusion of the above categories makes it likely that they were historically freer of bacterial infection than a random population sample would be. Sera were tested for precipitins against Staphylococcus, Haemophilus influenzae, Pneumococcus, Proteus, Pseudomonas aeruginosa, Klebsiella, and haemolytic streptococcus. Precipitins were estimated by the methods of Burns (1968) and Burns and May (1967, 1968).

\section{Results}

Normal series. Of 522 children, 55 had precipitins against one or more pathogens $(10.5 \%)$. A total of 61 precipitins were found. 6 had precipitins against two organisms as follows: Pneumococcus and Staphylococcus, 3 cases aged 7, 9, and 14. Pneumococcus and $H$. influenzae, 1 case aged 6. $H$. influenzae and Staphylococcus, 1 case aged 11. Klebsiella and Pneumococcus, 1 case aged 12.

The incidence of serum precipitins was found to rise steadily through childhood as follows: age 0-4 years $3 \cdot 6 \%$; age $5-9$ years $12 \cdot 3 \%$; age $10-15$ years $23 \cdot 2 \%$. No precipitins were found in 50 infants examined in the first year of life. Incidences for individual precipitins are shown in the Table.

In this normal population precipitins were for practical purposes not found against Pseudomonas, Klebsiella, and Proteus. Precipitins against haemolytic streptococcus were found at the rate of $3.4 \%$ in the middle quinquennium only. Precipitins against Pneumococcus were uncommon before the age of 10 , but rose to $5.3 \%$ in the third quinquennium. Precipitins against $H$. influenzae had a fairly stable incidence between $2 \cdot 1 \%$ and $3.4 \%$ in all three quinquennia. Precipitins against

TABLE

Incidence of precipitins in normal series by quinquennia

\begin{tabular}{|c|c|c|c|c|}
\hline & $\begin{array}{l}0-4 \text { years } \\
\text { (224 cases) }\end{array}$ & $\begin{array}{c}5-9 \text { years } \\
(203 \text { cases })\end{array}$ & $\begin{array}{c}10-15 \text { years } \\
(95 \text { cases })\end{array}$ & $\begin{array}{l}0-15 \text { years } \\
(522 \text { cases })\end{array}$ \\
\hline $\begin{array}{l}\text { Staphylococcus } \\
\text { Haemophilus influenzae } \\
\text { Pneumococcus } \\
\text { Proteus } \\
\text { Pseudomonas aeruginosa } \\
\text { Klebsiella } \\
\text { Haemolytic streptococcus } \\
\text { Any of above }\end{array}$ & $\begin{array}{l}1(0.45 \%) \\
6(2 \cdot 7 \%) \\
0(0.0 \%) \\
0(0.0 \%) \\
1(0.45 \%) \\
0(0.0 \%) \\
0(0.0 \%) \\
8(3.6 \%)\end{array}$ & $\begin{array}{c}10(4 \cdot 9 \%) \\
7(3 \cdot 4 \%) \\
4(2 \cdot 0 \%) \\
0(0 \cdot 0 \%) \\
0(0 \cdot 0 \%) \\
0(0 \cdot 0 \%) \\
7(3 \cdot 4 \%) \\
25(12 \cdot 3 \%)\end{array}$ & $\begin{array}{c}16(16 \cdot 8 \%) \\
2(2 \cdot 1 \%) \\
5(5 \cdot 3 \%) \\
0(0 \cdot 0 \%) \\
0(0 \cdot 0 \%) \\
1(1 \cdot 0 \%) \\
1(1 \cdot 0 \%) \\
22(23 \cdot 0 \%)\end{array}$ & $\begin{array}{c}27(5 \cdot 1 \%) \\
15(2 \cdot 9 \%) \\
9(1 \cdot 7 \%) \\
0(0 \cdot 0 \%) \\
1(0 \cdot 2 \%) \\
1(0 \cdot 2 \%) \\
8(1 \cdot 5 \%) \\
55(10 \cdot 5 \%)\end{array}$ \\
\hline
\end{tabular}

No precipitins in $\mathbf{5 0}$ cases in the first year of life. 
Staphylococcus rose steadily after the preschool years. None were found in the first 4 years of life, but the incidences for the second and third quinquennia were $4.9 \%$ and $16.8 \%$ respectively.

Cystic fibrosis series. The series of $\mathbf{4 8}$ cases of CF (38 surviving) treated with continuous cloxacillin for from 1 to 11 years since 1964, showed in January 1975 (or shortly before death before this date) the differences from the normal series which are shown in the Table. There were no significant differences in respect of Pneumococcus, Proteus, and Klebsiella, and the CF series were not tested against the haemolytic streptococcus.

\section{Discussion}

In the normal population no precipitins were found in the first year of life. No staphylococcal precipitins were found in the first 4 years, but subsequently the incidence rose from $4.9 \%$ in the second quinquennium to $16.8 \%$ in the third quinquennium. Precipitins against the pneumococcus were $2 \%$ in the second and $5.3 \%$ in the third quinquennium. The incidence of haemophilus precipitins was between $2 \cdot 1 \%$ and $3 \cdot 4 \%$ in all quinquennia. Precipitins against other organisms are rare, with the exception of haemolytic streptococcus which showed an incidence of $3.4 \%$ in the second quinquennium only.

The CF figures are markedly different. The well known predisposition of CF to $H$. influenzae and $P$ s. aeruginosa infection is confirmed, but it should be noted that cases in the third quinquennium have not had the benefit of continuous antistaphylococcal therapy since early diagnosis. Cases of CF are well known to be particularly prone to lung damage from staphylococcal infection. The present findings indicate that the development of staphylococcal precipitins can be prevented by continuous cloxacillin therapy, and that pre-existing staphylococcal precipitins disappear slowly on this treatment.

\section{Summary}

Well children show a steady increase of staphylococcal precipitins throughout life. Lower incidences are found for precipitins against $H$. influenzae, Pneumococcus, and haemolytic streptococcus. Precipitins against Proteus, Pseudomonas, and Klebsiella are rare. There are marked differences between the normal children and the cloxacillintreated children with cystic fibrosis in respect of Pseudomonas and $H$. influenzae which rise to over $50 \%$ of cystic fibrosis children in the third quinquennium. However, the development of staphy- lococcal precipitins can be prevented by continuous antistaphylococcal therapy.

We acknowledge the help of the late Dr. R. L. Newman, and thank the Cystic Fibrosis Research Trust for the grant which financed this investigation.

\section{REFERENCES}

Burns, M. W. (1968). Precipitins to pneumococcal C-substance polysaccharide in the serum of patients with chronic bronchial disorders. Lancet, 1, 223.

Burns, M. W., and May, J. R. (1967). Haemophilus influenzae precipitins in the serum of patients with chronic bronchial disorders. Lancet, $1,354$.

Burns, M. W. and May, J. R. (1968). Bacterial precipitins in serum of patients with cystic fibrosis. Lancet, 1, 270.

D. LAwsON ${ }^{\star}$ and JUdith PORTER

Queen Mary's Hospital for Children, Carshalton, Surrey SM5 4NR.

^Correspondence to Dr. D. Lawson.

\section{Frequency of other malformations in congenital hypoplasia of depressor anguli oris muscle syndrome}

The interest in the asymmetric crying facies due to congenital hypoplasia of the depressor anguli oris muscle (DAOM) has grown in recent years because of its association with congenital abnormalities and, more specifically, with congenital heart disease (Cayler, Blumenfeld, and Anderson, 1917). Papadatos et al. (1974) have reported on the possibility that the DAOM hyplopasia is a genetically determined condition. This paper compares the frequency of congenital abnormalities in neonates with and without DAOM hypoplasia.

\section{Material and methods}

All newborn infants born between 1 August 1972 and 1 December 1973 at Alexandra Maternity Hospital were specifically examined for the presence of DAOM hypoplasia or for other congenital abnormalities. There were 6487 neonates, 3314 males and 3173 females. DAOM hypoplasia was observed in $\mathbf{4 4}$ newborns; on all of whom $x$-rays of the heart and of the whole skeleton were taken, as well as an electrocardiogram. One year after delivery 32 of the 44 neonates with DAOM hypoplasia were located and examined for the purpose of detecting additional congenital anomalies. A complete physical and cardiological examination was done, as well as a careful urinalysis and a BM nitrit test (Fuchs and Gutensohn, 1967) for detection of possible pyelonephritis due to anomalies of the urinary tract. In the group of newborns without DAOM hypoplasia 29 suffered from congenital heart disease. 19 of them were 
Erratum - This Table replaces that on page 890 in the November issue, from which data had been omitted.

TABLE

Incidence of precipitins in normal and CF series by quinquennia

\begin{tabular}{|c|c|c|c|c|}
\hline Normal* & $\begin{array}{l}0-4 \text { years } \\
(224 \text { cases })\end{array}$ & $\begin{array}{c}5-9 \text { years } \\
(203 \text { cases })\end{array}$ & $\begin{array}{l}10-15 \text { years } \\
\text { (95 cases) }\end{array}$ & $\begin{array}{l}0-15 \text { years } \\
(522 \text { cases })\end{array}$ \\
\hline $\begin{array}{l}\text { Staphylococcus } \\
\text { Haemophilus influenzae } \\
\text { Pneumococcus } \\
\text { Proteus } \\
\text { Pseudomonas aeruginosa } \\
\text { Klebsiella } \\
\text { Haemolytic streptococcus } \\
\text { Any of above }\end{array}$ & $\begin{array}{l}1(0 \cdot 45 \%) \\
6(2 \cdot 7 \%) \\
0(0.0 \%) \\
0(0 \cdot 0 \%) \\
1(0.45 \%) \\
0(0.0 \%) \\
0(0.0 \%) \\
8(3 \cdot 6 \%)\end{array}$ & $\begin{array}{c}10(4 \cdot 9 \%) \\
7(3 \cdot 4 \%) \\
4(2 \cdot 0 \%) \\
0(0 \cdot 0 \%) \\
0(0 \cdot 0 \%) \\
0(0 \cdot 0 \%) \\
7(3 \cdot 4 \%) \\
25(12 \cdot 3 \%)\end{array}$ & $\begin{array}{c}16(16 \cdot 8 \%) \\
2(2 \cdot 1 \%) \\
5(5 \cdot 3 \%) \\
0(0 \cdot 0 \%) \\
0(0 \cdot 0 \%) \\
1(1 \cdot 0 \%) \\
1(1 \cdot 0 \%) \\
22(23 \cdot 0 \%)\end{array}$ & $\begin{array}{c}27(5 \cdot 1 \%) \\
15(2 \cdot 9 \%) \\
9(1 \cdot 7 \%) \\
0(0 \cdot 0 \%) \\
1(0 \cdot 2 \%) \\
1(0 \cdot 2 \%) \\
8(1 \cdot 5 \%) \\
55(10 \cdot 5 \%)\end{array}$ \\
\hline$C F(n=47 \dagger)$ & $\begin{array}{l}0-4 \text { years } \\
(15 \text { cases })\end{array}$ & $\begin{array}{l}5-9 \text { years } \\
(14 \text { cases) }\end{array}$ & $\begin{array}{l}10-15 \text { years } \\
\text { (18 cases) }\end{array}$ & \\
\hline $\begin{array}{l}\text { Staphylococcus } \\
\text { Haemophilus influenzae } \\
\text { Pseudomonas aeruginosa }\end{array}$ & $\begin{array}{l}0(0 \%) \\
3(20 \% \%) \\
2(13 \%)\end{array}$ & $\begin{array}{l}0(0 \%) \\
1(7 \%) \\
3(21 \%)\end{array}$ & $\begin{array}{l}0(0 \%) \\
10(56 \%) \\
10(56 \%)\end{array}$ & \\
\hline
\end{tabular}

* No precipitins in 50 cases in the first year of life.

+ Total is 47 , not 48 , as one patient aged 17 is excluded. 